\title{
Dissatisfied consumers' complaint behaviour concerning product failure of major electrical household appliances - a conceptual framework *
}

\author{
Suné Donoghue and Helena M de Klerk
}

\begin{abstract}
Opsomming
Verbruikers se ontevredenheid met produkte manifesteer in hulle klagte-gedrag. Verbruikers se klagtes word oor die algemeen in ' $n$ negatiewe lig beskou, aangesien dit met hulle ontevredenheid oor ' $n$ bepaalde produk of diens geassosieer word. Verbruikers se klagtes moet egter as voordelig vir die vervaardiger, kleinhandelaar en die verbruiker beskou word, aangesien dit onder andere dien as inligting wat deur verbruikers geïnisieer is om strategiese besluitneming vir kleinhandelaars en vervaardigers te vergemaklik. Verbruikers kan op hulle beurt vir produkprobleme vergoed word en op hulle regte as verbruikers aandring. Vervaardigers en kleinhandelaars kan egter net van verbruikers se behoeftes en probleme ten opsigte van produkte bewus word wanneer verbruikers dit aan hulle kommunikeer. 'n Konseptuele raamwerk word aangebied vir die bestudering van ontevrede verbruikers se klagte-gedrag as reaksie op die funksionele en / of simboliese produkmislukking (product failure) van groot elektriese huishoudelike toerusting. Die konfirmasie / diskonfirmasie-paradigma, Day en Landon se klagte-gedrag-taksonomie, Weiner se attribusieteorie en spesifieke verbruikers- en produkveranderlikes wat verband hou met klagte-gedrag dien as teoretiese agtergrond vir die konseptuele raamwerk.
\end{abstract}

\section{- Ms S Donoghue}

Department of Consumer Science

University of Pretoria

- Prof HM de Klerk

Department of Consumer Science

University of Pretoria
* The authors would like to thank the reviewers for their time and valuable recommendations

\section{INTRODUCTION}

One of the advantages of a modern economy is that the marketplace can provide the consumer with an adequate choice of goods and services as well as the likelihood of satisfaction with that choice. In an ideal world, every product and service would be delivered flawless. However, sometimes products and services turn out not to be so perfect, necessitating the promotion of consumers' rights to develop a consumeroriented culture. Considering numerous letters of complaint in the consumer column of the Beeld and other newspapers as well as online letters to consumer complaint websites (such as hello.peter.co.za) it is clear that South African consumers experience a considerable amount of problems with the performance of their major electrical household appliances. Additionally, consumer bodies such as the National Consumer Union and various provincial consumer counsels deal with numerous consumer complaints concerning major electrical appliances on a regular basis. Whereas South African business organisations need to ensure consumers' rights, i.e. the right to information, the right to choose, the right to safety and the right to be heard, consumer scientists must function as the link between consumers and the marketplace. In order to do so, and to execute trustworthy research in this regard, they need a well-planned scientific conceptual framework that can serve as point of departure for the research. The aim of this article is therefore to supply future researchers with a conceptual framework for researching dissatisfied consumers' complaint behaviour concerning the product failure of major electrical household appliances.

The consumption evaluation process can be described as a confirmation/disconfirmation paradigm (Churchill \& Suprenant, 1982 Francken, 1983) whereby consumers compare their initial expectations for product performance with perceived product performance and notice whether a difference (expectancy disconfirmation) exists (Woodruff et al, 1983; Day, 1984; Blogett \& Granbois, 1992). Whereas confirmation occurs when a product performs as expected, contributing to satisfaction or indifference (neutral feelings), positive and negative disconfirmation arises from discrepancies between prior expectations and actual performance, respectively leading to satisfaction and dissatisfaction (Swan \& Combs, 1976; Oliver \& DeSarbo, 1988; Erevelles \& Leavitt, 1992; Chen-Yu et al, 1999). Consumer satisfaction/dissatisfaction (CS/D) is therefore generally conceptualised as a positive/negative feeling (emotion), in response to, or following, a specific consumption experience 
(Woodruff et al, 1983; Westbrook, 1987; Swan \& Oliver, 1989; Erasmus \& Donoghue, 1998).

Complaints, as an outcome of dissatisfaction, are in many cases perceived in a negative manner. However, complaints reveal problems that, in many cases are significant and deserve the attention of retailers and manufacturers (Landon, 1980). Complaints can inform retailers and manufacturers about consumers' existing needs and provide the opportunity for discussion about future needs (Sanes, 1993). Viewed in this manner, complaining may be very useful for the retailer and manufacturer in discovering and correcting product problems, increasing consumer satisfaction, retaining the consumer as an active purchaser and increasing market place efficiency, rather than simply pacifying unhappy consumers or providing an excuse and/or appropriate form of redress (Hill et al, 2000; Hogarth \& English, 2002; Consumer Alert, 2003). Consequently, consumer complaints can be considered very useful forms of consumer-initiated market information that can be used to make strategic and tactical decisions (Nyer, 2000).

Retailers and manufacturers can only become aware of product shortcomings and remedy the problem when consumers directly communicate their dissatisfaction to them, while consumer scientists can only assist unhappy consumers when they know how they think and why they are complaining. Organisational resistance to paying attention and responding to consumer complaints increases the likelihood that consumers will complain in private (i.e., negative word-ofmouth to family and friends) and to third parties (ombudsmen, local consumer agencies, trade associations etc.) (McAlister \& Erffmeyer, 2003). Negative word-of-mouth actions taken by dissatisfied consumers can damage the company's reputation (Richins, 1983; Clopton et al, 2001), resulting in the loss of potential and existing consumers (Stephens \& Gwinner, 1998), as well as impacting on the company's revenue (Sanes, 1993; Broadbridge \& Marshall, 1995). Efficient complaining furthermore has important implications for the individual consumer. Apart from the possibility of obtaining redress, the act of complaining in itself also has various psychological benefits (Bennet, 1997; Nyer, 2000). Depending on the psychological makeup of the individual, complaint action might be viewed as an opportunity to stand up for one's rights or as an unpleasant and degrading hassle (Day et al, 1981).

Researchers in consumer behaviour have been studying consumer responses to dissatisfactory consumption experiences for many years. In fact, the topic of consumer satisfaction, dissatisfaction and complaining behaviour is one of the most studied issues in the field of consumer behaviour. So much so that many international conferences have been held and academic articles have been published in scientific journals. Additionally, a bibliography has been compiled containing numerous articles, written in English and other languages, on the topic of consumer satisfaction/ dissatisfaction and complaining behaviour (Perkins, 1993). Despite the immense international interest in the topic, very little research concerning the topic and no scientific research about the dissatisfied consumer's complaint behaviour concerning major electrical household appliance could be found in the South African context. D Rousseau's (2003:446-471) research and writings have contributed to researchers' understanding of consumers' post-purchase behaviour, especially complaint behaviour. GG Rousseau's (1988) study on consumers' and retailers' perceptions of product failure identified household appliances as a major failure category. For the purpose of this study, major electrical household appliances refer to kitchen and laundry appliances namely refrigerators, freezers, ovens, stoves, dishwashers, microwave ovens, washing machines and tumble dryers. These energy- and time-saving devices are important products without which many households would not be able to function effectively. Moreover, these appliances are in general expensive, complex and expected to be durable. It is therefore of the utmost importance that consumers should be satisfied with their choice, and if not, that the retailer and manufacturer should know the reason (s) for their dissatisfaction. A knowledge void exists concerning the South African dissatisfied consumer's complaint behaviour regarding major electrical household appliances.

In order to develop a conceptual framework that will enable the researcher to address the problem, this article will firstly focus on the concept of consumer complaint behaviour, and secondly on attribution theory, as a theoretical perspective that concentrates on the underlying perceptions and cognitions that individuals use to explain perceived causality.

\section{CONSUMER COMPLAINT BEHAVIOUR}

Traditionally, studies on consumer complaint behaviour have focused on behavioural responses, that is, those consumer actions that directly convey an "expression of dissatisfaction" (Landon in Singh, 1988). These behaviours include complaints directed to second parties (manufacturers and retailers), complaints to third parties (public consumer protection agencies, voluntary organisations, ombudsman or court) and telling friends and family (Singh, 1988; Halstead \& Dröge, 1991).

Several studies have examined formal complaint actions or intentions. However, conceptualising consumer complaint behaviour as only formal complaint behaviour is generally considered exceedingly restrictive (Singh, 1988; Halstead \& Dröge, 1991). Generally, it has been found that relatively fewer formal complaints are made than would be expected from expressed levels of dissatisfaction (Barnes \& Kelloway, 1980; Ash in Oliver, 1987; Dolinsky, 1994). Additionally, a large majority of dissatisfied consumers never complain to the retailer, manufacturer or a third party. Therefore, since we can safely assume that retailers, manufacturers and third parties receive complaints or requests for redress from an unrepresentative sample of the total population of consumers who have experienced dissatisfaction, complaint statistics 
grossly understate the frequency of dissatisfaction (Day \& Landon, 1976; Landon, 1980; Day et al, 1981).

Contrary to formal complaints, which are evident to retailers and manufacturers, the typical dissatisfied consumer takes part in a variety of "hidden" or indirect activities including boycotting the retailer, changing brands, boycotting the product type, and engaging in adverse word-of-mouth "marketing" (Day et al, 1981; Richins, 1987; Goodwin \& Spiggle, 1989). Both retailers and manufacturers in many cases underestimate the detrimental effect of such indirect activities. Whereas many dissatisfied consumers take these hidden actions instead of directly complaining to formal complaint parties, many consumers who do complain formally also engage in hidden actions (Day et al, 1981; Kincade et al, 1998). Moreover, dissatisfied consumers will typically tell eight to ten people about their problem (Plymire, 1991; Sanes, 1993). In fact, studies show that consumers tell twice as many people about unresolved negative experiences as about positive ones (Loudon \& Della Bitta, 1993:581). Consequently, far larger numbers of unknown dissatisfied consumers respond in covert ways that never come to the retailer's or manufacturer's attention (Day et al, 1981).

Furthermore, numerous studies have documented that a common response to consumer dissatisfaction is to "do nothing". By taking no action, the consumer effectively decides to tolerate the dissatisfaction or to rationalise it, or to forget it and do nothing (Day \& Landon, 1977:429, 732; Singh, 1988; Hawkins et al, 1998:621). A primary reason for taking no action is that action requires time and effort that may exceed the perceived value of any likely result. However, even when no action is taken, one's attitude toward the store or brand is likely to be less favourable than before (Hawkins et al, 1998:621). Non-behavioural responses should be considered legitimate forms of consumer complaining, despite its passive nature (Singh, 1988; Halstead \& Dröge, 1991). The inclusion of non-behavioural responses as forms of consumer complaining, appears not to be only justified, but nec- essary to comprehend the process underlying the consumer complaint behaviour response (Singh, 1988).

Consumer complaint behaviour responses may therefore be considered to be either behavioural or nonbehavioural (Singh, 1988, Morel et al, 1997). Singh (1988) in particular argues that consumer complaint behaviour should be conceptualised as "a set of multiple (behavioural and non-behavioural) responses, some or all of which are triggered by the perceived dissatisfaction with a purchase episode".

While there is considerable consensus about the conceptual meaning of the consumer complaint behaviour construct, only a few researchers have offered specific models for dissatisfaction responses, some of which seem valid and useful (Hirschman, 1970 3-4; Day \& Landon, 1977:425-437; Singh, 1988), while others are questionable (Maute \& Forrester, 1993; Morel et al, 1997).

Day and Landon's (1976) taxonomy of consumer complaint behaviour, in Figure 1, has achieved wide acceptance in consumer complaint behaviour literature (Broadbridge \& Marshall, 1995). Under their taxonomy, three major options are available to consumers who are dissatisfied with their purchase: no action, private action or public action. Consumers may refrain from action by rationalising and forgetting the problem. Consumers may engage in private actions such as warning family and friends about the product and/or seller, boycotting the type of product and switching brands or retailers. Additionally, consumers may engage in public action such as seeking redress (i.e. a refund, an exchange or free repairs and replacement of defective parts, depending on the nature of the product and particular circumstances) directly from the retailer or manufacturer, complaining to the retailer or manufacturer, a public consumer protection agency, a voluntary organisation or the media, or taking legal action against the retailer or manufacturer (Day \& Landon, 1977:229-432; Day \& Bodur, 1978; Broadbridge \& Marshall, 1995).

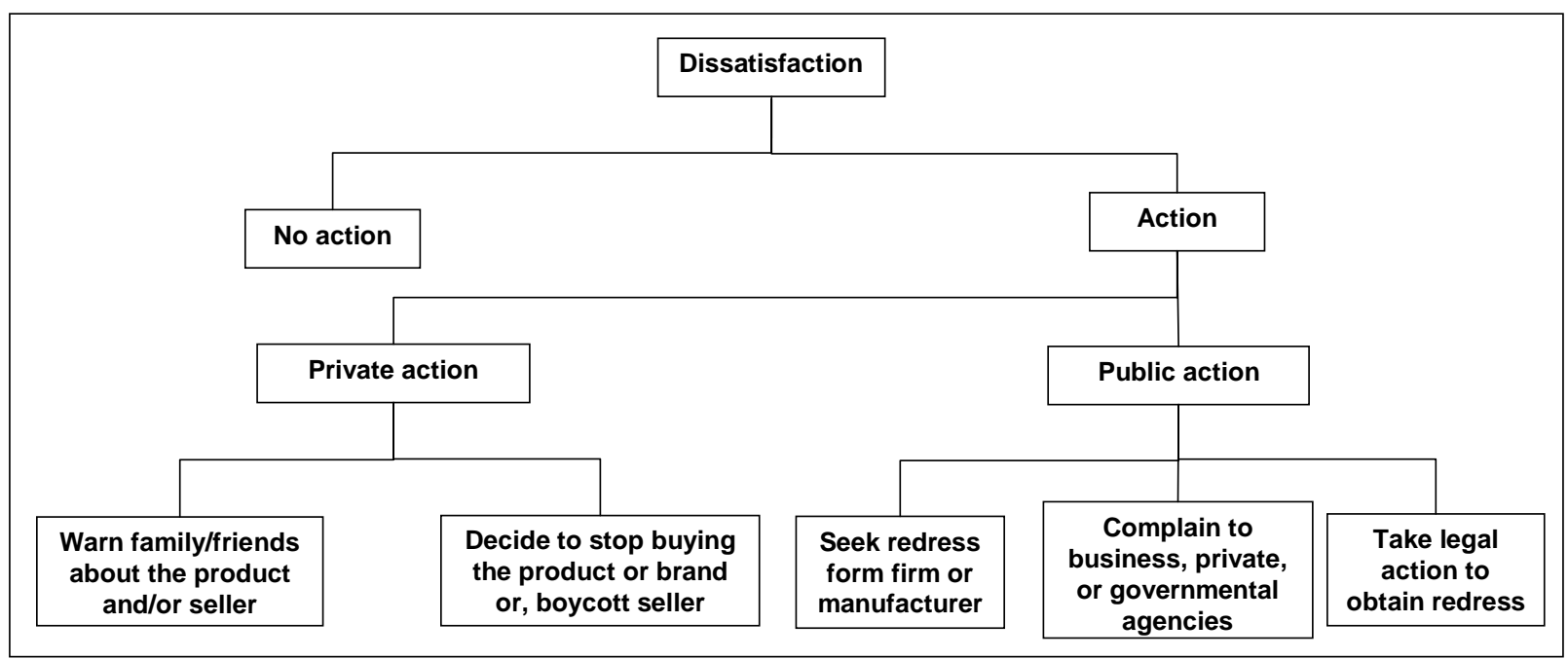

FIGURE 1:

A TAXONOMY OF CONSUMER COMPLAINT BEHAVIOUR (Day and Landon, 1977:432) 
The primary decision is, however, whether to take some form of action or no action at all. Whereas the first level distinction between action and no action logically follows from the conceptualisation of consumer complaint behaviour, Day and Landon (1976) seem to justify the public/private dichotomy (the second level of distinction) on the grounds of the nature and importance of the product which is causing the dissatisfaction together with the evaluation of the effort required and perceived outcome of the action. They hypothesise that complex and expensive products, such as major electrical household appliances, encourage more action to be taken publicly but feel that "the chances that the consumer will do nothing at all or only take private action are lower but still appear to be substantial" (Day \& Landon, 1977:432; Maute \& Forrester, 1993; Broadbridge \& Marshall, 1995; Stephens \& Gwinner, 1998).

Although dissatisfied consumers may engage in various combinations of behavioural actions or do nothing (Richins, 1983; Folkes, 1984; Singh \& Wilkes, 1996), research on consumer complaint behaviour, except for a few studies, has either failed to acknowledge this fact, or has focused on only one consumer complaint behaviour action (Richins, 1987; Singh, 1988). Researchers therefore need to recognise the multidimensionality of the consumer complaint behaviour construct and that studies investigating a range of consumer complaint behaviour responses are essential (Halstead \& Dröge, 1991).

\section{Factors affecting consumer complaint behaviour}

Although many researchers would agree with the central concept that dissatisfaction is a fundamental determinant for complaining behaviour (Singh, 1988; Morel et al, 1997), most would qualify this proposition to include additional variables beyond satisfaction to fully explain consumer complaint behaviour (Day, 1984; Jacoby \& Jaccard in Oliver, 1987; Halstead \& Dröge, 1991). Many studies indicate that the consumer's response to dissatisfaction is heavily influenced by individual characteristics. However, like all aspects of consumer behaviour, the product and situation are also important factors (Goodwin \& Spiggle, 1989).

Consumer-related variables Consumer-related variables refer to characteristics that are associated or determined primarily by consumers (i.e. individual factors). Consumer characteristics which may affect complaining behaviour decisions include among other things: demographics (Bearden \& Oliver, 1985; Bolfing, 1989), personality factors (Bolfing, 1989; Sheth et al, 1999:551), attitudes (Richins, 1982; Halstead \& Dröge, 1991), personal values (Keng \& Liu, 1997; Roger \& Williams in Stephens \& Gwinner, 1998; Liu \& McClure, 2001), culture (Day et al, 1981; Richins, 1987), knowledge and experience as consumers (Singh, 1990a; Sujan in Somasundaram, 1993; Broadbridge \& Marshall, 1995), and causal attributions for product failure (Folkes, 1990:144; Weiner, 2000; Laufer, 2002).
The incidence and likelihood of complaining has been found to vary based on individual consumer demographic characteristics (Dolinsky, 1994). Complainers tend to hold professional jobs, earn higher incomes, are well educated, and younger than non-complainers (Singh, 1990b; Warland et al in Broadbridge \& Marshall, 1995). Some authors, however, dispute this and have proposed that the "elderly, poor and individuals low in education do not necessarily react more passively to perceived dissatisfaction" (Gronhaug \& Zeltman in Broadbridge \& Marshall, 1995). Nevertheless, in general, findings have been fairly consistent with regard to age, income, education and profession as possible determinants of consumers' propensity to complain (Broadbridge \& Marshall, 1995).

Consumers' personality traits and psychological characteristics play an important role in complaining behaviour. Consumers differ in self-confidence and in their degree of aggressiveness or submissiveness. Complainers have been found to be more assertive, self-confident and in personal control of their life experiences (internal control) relative to non-complainers (Landon in Bolfing, 1989; Singh, 1990a; Sheth el al, 1999:551). However, it should be pointed out that researchers have found that most demographic variables and underlying personality traits provide very little explanatory power in explaining differences in consumer complaining behaviour (Richins, 1987; Robinson in Blogett \& Granbois, 1992; Stephens \& Gwinner, 1998). Goodwin and Spiggle (1989) propose that a consumer's self-definition as a complainer may also affect complaining decisions. In making a complaint, the consumer needs to take on the role-identity of "complainer". People are reluctant to include this identity as part of the "self" because they tend to disassociate themselves strongly from negative identities (McCall \& Simmons in Goodwin \& Spiggle, 1989). This might explain why people often do not like to complain or do not take part in complaint activities.

Several studies support the role of attitudes toward complaining as direct positive antecedents of either complaining intentions or complaining behaviour (Richins, 1982; Day, 1984; Bearden \& Crocket in Halstead \& Dröge, 1991). Singh in Halstead and Dröge (1991) indicated that the normative dimension of attitude ("I should complain") positively and significantly influenced consumers' intention to seek redress. Consumers who have a favourable attitude toward complaining will be more likely to seek redress from the retailer (Beardon \& Mason in Blodgett \& Granbois, 1992; Singh in Kincade et al, 1998). Consumers' attitudes toward business, government, consumer organisations and complaining have been studied in order to predict complaining behaviour, but the results have been mixed (Barnes \& Kelloway, 1980; Halstead \& Dröge, 1991).

Keng and Liu (1997) investigated the relationship between personal values and complaint behaviour in an Asian setting. Respondents made a selection from a list of values according to which they were categorised as self-oriented or as group-oriented. Group-oriented 
consumers resorted to private action, while their selforiented counterparts were more prepared to opt for public actions.

Research has indicated that consumers in different cultures have different complaint behaviours and intentions (Day et al, 1981; Richins, 1987; Liu \& McClure, 2001). Liu and McClure's (2001) study empirically confirmed that when dissatisfied, consumers in a collectivistic culture (South Korean consumers) are less likely to engage in voice behaviour but are more likely to engage in private behaviour than those in an individualist culture (US consumers). Crosscultural differences might explain variation in the relationship between word-of-mouth and product problem variables for American and Dutch consumers (Richins, $1983 \& 1987)$.

Different motivations for purchase and different experiences in the past can affect both the consumer's evaluations and post-purchase behaviour (Day, 1977; Day, 1984). The consumer with considerable experience in purchasing and using any product or service will have had an opportunity to learn the key dimensions of performance of an item and develop a basis for forming specific prior expectations of performance and for evaluating actual performance. The inexperienced consumer, on the other hand, will presumably perform more poorly both as a buyer and as an evaluator (Day, 1977). Singh (1990b) found that prior experiences provide part of the descriptors for predicting redress behaviour, specifically complaint behaviour. In general, complainers tend to have more prior experience of complaining compared to noncomplainers. Knowledge of unfair practices, consumer rights and where and how to make complaints has been found to co-vary positively with complaining behaviour (Singh, 1990b). The more knowledgeable consumer is less likely to have an unsatisfactory experience, and is more likely to be able to resolve it on his/her own or to obtain redress with relatively little friction (Day \& Landon, 1977:434). The less knowledgeable and more inexperienced consumer will be less able to judge product performance and evaluate the goods and services that he/she consumes. In addition, such a consumer will be unfamiliar with procedures for seeking redress and registering complaints (Day \& Landon, 1976; Day, 1977; Barnes \& Kelloway, 1980).

The role of attributional processing in consumer complaint behaviour has been studied by numerous researchers (Folkes, 1990:150-155; Weiner, 2000; Laufer, 2002). Since particular attention is given to attribution theory and its application to consumer complaint behaviour in this article, it is only mentioned in this section as a comprehensive discussion follows in the section about attribution theory.

Very little, if anything, is known about the influence of these characteristics on the complaint behaviour of consumers of major electrical household appliances, and it is therefore proposed that all these factors be included in a comprehensive conceptual framework. It would, however, probably be unfair to expect of one single research project to investigate the influence of all the aforementioned factors; they should rather be categorised as demographics, personality factors and others.

Product-specific variables Product-specific variables related to complaint behaviour include: the nature or type of product (product category) (Kincade et al, 1998, cost of the product (Gilly \& Gelb in Kincade et al, 1998; Stephens \& Gwinner, 1998), durability (Day \& Landon, 1977:434; Kincade et al, 1998), importance of the product to the consumer (Stephens \& Gwinner, 1998; Sheth et al, 1999:550), dissatisfaction with the product (Day \& Bodur, 1978; Bearden \& Teel in Goodwin \& Spiggle, 1989), the type of product failure (Kincade et al, 1998), and severity of the dissatisfaction or problems caused by the dissatisfaction (Richins, 1987; Goodwin \& Spiggle, 1989).

Major electrical household appliances are mainly purchased with the intention to aid household members in doing household tasks. However, these products might also be important as an identity extension, to seek prestige and to reflect personal and family goals and aspirations or social position in the community (Donoghue, 1998:105-108; Fournier et al in Erasmus, 1998).

The functional and symbolic performance dimensions of products relate to the type of product failure. Kincade et al (1998:84) define product failure as "the failure of the product to maintain the desired quality after purchase". For analysis, Kincade et al (1998) grouped product failures into two categories: those that rendered the product unusable (i.e. functional performance failure) and those failures that may change the appearance but left the product usable (symbolic performance failure). Whereas functional performance refers inter alia to durability, ease of use, ease of care and physical performance (how well the product does what it is supposed to do), a product's symbolic performance refers to a "psychological" level of performance, such as what the product does for, or symbolises to, the consumer, which are not direct properties of the physical product, but are derived from the consumer's response to the physical product (Swan \& Combs, 1976; Abraham-Murali \& Littrell, 1995; Brown \& Rice, 1998:38-39; Erasmus \& Donoghue, 1998; Hawkins et al, 1998:620).

Some dissatisfactions are relatively minor and may not justify the effort to make a complaint (Maute \& Forrester, 1993). However, some such as complete product breakdown or safety hazards of a defective product are more serious and thus more likely to result in complaint action (Barnes \& Kelloway, 1980; Richins \& Verhage, 1985). The decision of how to respond to an unsatisfactory product thus appears to be determined by the severity of the problem.

In the South African marketing environment where there exists a major knowledge void regarding consumers' satisfaction with their choice of major electrical household appliance, it is of the utmost importance that consumers' complaint behaviour regarding the 
product performance failure should be studied hence this conceptual framework.

Redress environment variables Redress environment variables refer to factors that are controlled or primarily influenced by retailers. Although redress environment variables influence consumer complaint behaviour, it is not the focus for the development of this specific conceptual framework.

It is, however, important to note that consumers are more likely to voice their complaints when there is a more positive perception of retailer responsiveness to consumer complaints (Richins, 1983; Loudon \& Della Bitta, 1993:581; Sheth et al, 1999:550), while consumers who perceive the probability of success to be low are more likely to take their custom elsewhere and/or engage in negative word-of-mouth behaviour (Singh in Blodgett \& Granbois, 1992). If the complaint handling mechanism for the unsatisfactory product does not cause the consumer to go through a great deal of inconvenience, the likelihood of complaining may be increased (Richins \& Verhage, 1985; Halstead \& Dröge, 1991; Dolinsky, 1994). The consumer's evaluation of the retailer's response to the complaint in terms of the fairness of the redress offered and the fairness of the procedures used in settling the complaint (i.e., perceived justice), will largely determine whether that consumer will engage in consumer complaint behaviour (Goodwin \& Ross, 1990; Blodgett \& Granbois, 1992; Sheth et al, 1999:551).

\section{ATTRIBUTION THEORY}

In the next section attribution theory, as part of social cognition, is discussed. Additionally, an overview of the application of Weiner's attributional theory in social psychology and in consumer behaviour is discussed.

\section{Attribution as part of social cognition}

Every day, people encounter events or situations that require explanation. They often ask questions pertaining to why certain things happened to them (Fiske \& Taylor, 1991:22; Kelly in Försterling, 2001:4). Part of their perceptual process is aimed at interpreting the reasons for events (Williams, 1982:70-71). Under circumstances where events are considered insignificant the attribution process may be almost automatic. However, there are many circumstances in which causal analyses are more intentional, deliberate and time-consuming. After all, people typically do not ask why they did well in an exam, or why they received warm greetings from a friend, but rather why they failed and why they received rejection from a friend (Fiske \& Taylor, 1991:22; Weiner, 2000). Individuals are more likely to engage in attributional reasoning when they are surprised or threatened by unexpected, negative or important events that undermine their beliefs and expectations (Weiner, 1986:127 \& 2000; Wong \& Weiner in Fiske \& Taylor, 1991:22; Bougie et al, 2003). Therefore, deviation from a normal course of events acts as a condition for causal reasoning
(Einhorn \& Hogarth in Hewstone, 1989:45).

Attribution theory explains the perceived causality of social behaviour in terms of cognitive rules or implications (Sirgy, 1983:3; Lennon \& Davis, 1989). The central focus of attribution research lies in the investigation of thoughts or cognitions: how individuals select, process, store, recall and evaluate information and how the information is then used to draw causal inferences (Försterling, 2001:10). Attribution theorists therefore assume that there are some systematic processes by which attributions are made and that the attributions that people arrive at have some consequences for future behaviour (Folkes, 1988; Davis \& Lennon, 1991:183; Vaidyanathan \& Aggarwal, 2003).

It is important to note that there is a difference between attribution theory and attributional theories (Kelly \& Michela, 1980; Fiske \& Taylor, 1991:23; Försterling, 2001:8) (Figure 2).

Whereas attribution theory and research study the determinants of causal ascriptions (i.e. how the perceiver uses information to arrive at causal explanations for events), attributional theories investigate the consequence of causal cognitions (the influence attributions exert on e.g. emotions and behaviours). Attribution theory is concerned with the generic causal principles that people employ that might be used in a wide variety of domains. Attributional theories, on the other hand, are concerned with the specific causal attribution process that people employ in a particular life domain (Fiske \& Taylor, 1991:23; Försterling, 2001:8). Attribution research involves the systematic assessment or manipulation of antecedents. There is no interest in consequences beyond the attributions themselves, and they (the attributions) are generally measured directly by verbal report. Studies focusing on attributional consequences also manipulate antecedents, in the sense that research only manipulates information given to subjects and cannot directly include or measure cognitions. Essentially, perceived causes (i.e. causes that are not necessarily the "true" causes of things) are assessed or manipulated and their effects on various behaviours, feelings and intentions are measured (Kelly \& Michela, 1980; Weiner, 1986:22-23;243-275; Folkes, 1988). Whereas each type of research has its own focus, many studies have examined both. However, both types of research have in common an interest in the causal explanations given for events by ordinary people (Kelly \& Michela, 1980; Folkes, 1988).

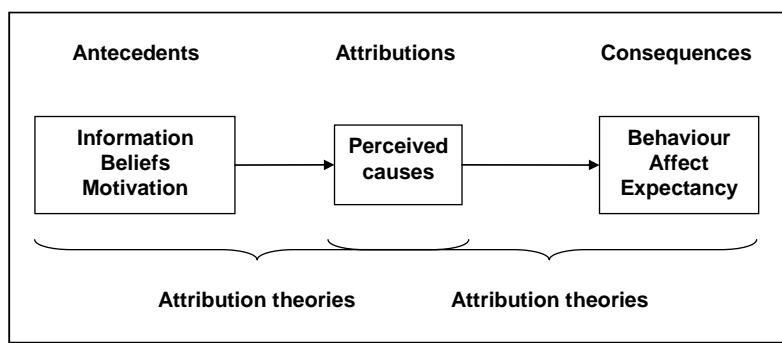

FIGURE 2: THE BASIC STRUCTURE OF ATTRIBUTION CONCEPTIONS (Kelly \& Michela, 1980:459) 
Research has pinpointed a number of persistent biases that people employ in the attribution process (Folkes, 1988; Fiske \& Taylor, 1991:93). The question of how consumers arrive at attributions and why certain patterns occur may be important from an attribution theory point of view. An awareness of biases in terms of attributional theory may be useful in explaining the consequences of attributional thought. Important attribution errors inter alia include the fundamental attribution error and self-serving attributional bias. The fundamental attribution error claims that people over attribute the behaviour of others to dispositional qualities rather than to situational factors. The actor observer effect implies divergent attributions for actors' and observers' behaviour, i.e. situational attributions for actors' behaviours; and dispositional attributions for observers' behaviours. Self-serving attributional bias refers to people's preference to take credit for good outcomes and to attribute bad ones to external factors (Fiske \& Taylor, 1991:67, 93; Försterling, 2001:103-105).

\section{An overview of Weiner's theory in social psychology}

Weiner's work on attribution theory is notable primarily for (i) developing the dimensions of attributional experience (i.e. a set of focal dimensions along which attributions may be inferred), (ii) integrating attribution with emotional processes, and (iii) enlightening the attributional and affective experience that underlies achievement behaviour, helping behaviour and other concrete domains of experience (Fiske \& Taylor, 1991:41, 55-56). Weiner's attributional analysis of achievement behaviour is the most comprehensive theoretical model about the influences of attributions on cognitive processes, affect and behaviour. Although Weiner's work was developed initially to explain achievement motivation, it also guided the theoretical analysis and empirical investigation of other motive systems and additional psychological phenomena with an attribution framework (Weiner in Folkes, 1984 \& 1988; Fiske \& Taylor, 1991:54, 56; Försterling, 2001:109). His framework is intended to be perfectly general and not limited to specific contexts (Weiner, 1986:3; Oliver, 1989).

Weiner's (1986) attributional theory of achievement motivation describes basic dimensions that people use to understand their success and failure, namely (i) locus of causality, (ii) stability, and (iii) controllability (Fiske \& Taylor, 1991:429). Locus of causality refers to the familiar location of a cause internal or external to the person; stability refers to the temporal nature of a cause, varying from stable (permanent) to unstable (temporary); and controllability refers to the degree of volitional influence that can be exerted over a cause (Weiner, 2000; Laufer, 2002; Vaidyanathan \& Aggarwal, 2003). Each of these dimensions is perceived as a bipolar continuum. Causes can theoretically be classified within one of eight cells (2 locus levels $\times 2$ stability levels $\times 2$ controllability levels) (Hewstone, 1989:33; Folkes, 1984; Oliver, 1989). Weiner's influential taxonomy for causal attributions allows one to classify phenotypically different causal attributions (e.g. lack of ability, or lack of effort, or illness) according to their genotypical similarities (i.e, that they reside within the person) (Weiner, 1986:17, 44-45; Försterling, 2001:110-111). Weiner demonstrated that, despite the large number of perceived causes for any one event, the specific type of cause attributed to an

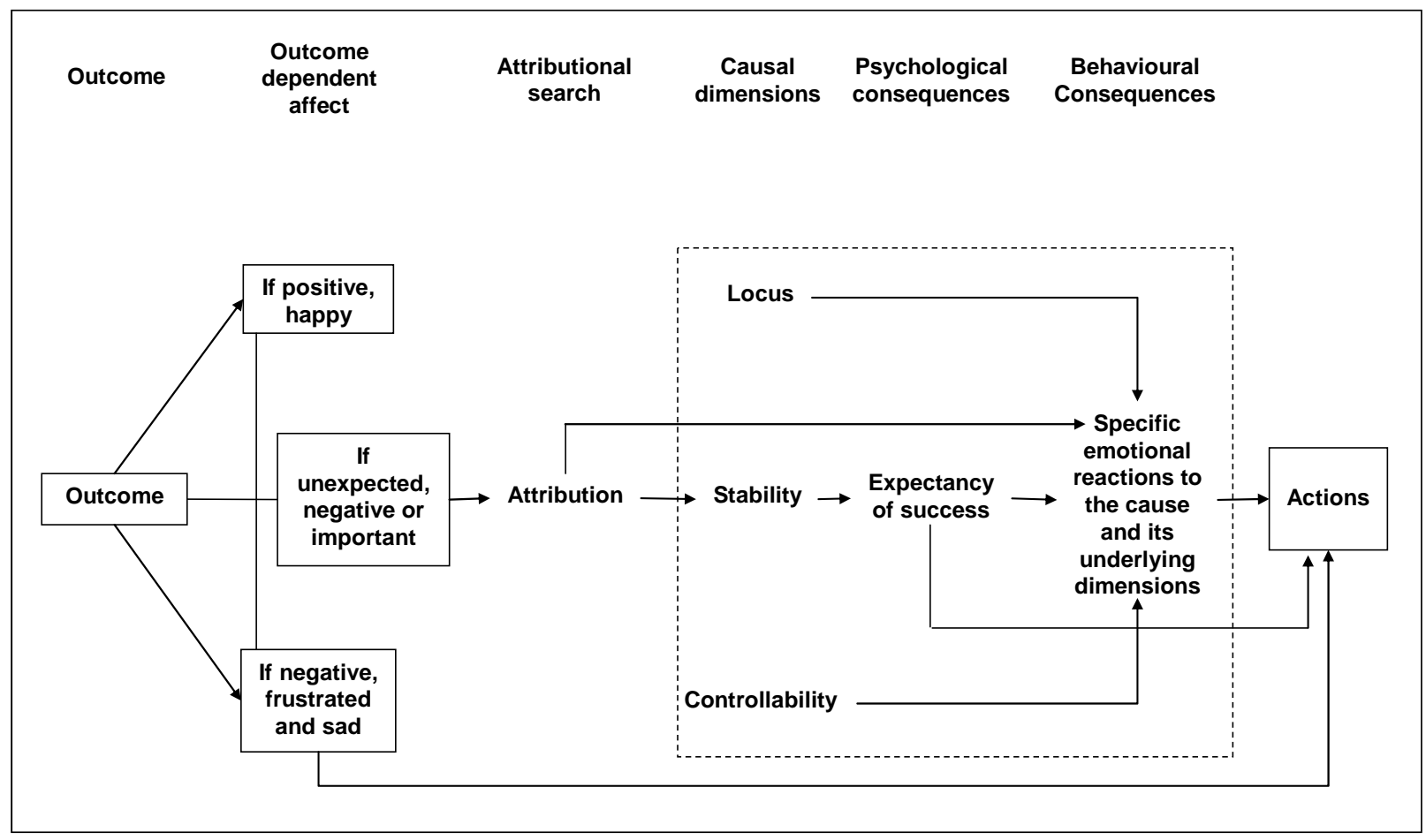

FIGURE 3: $\quad$ AN ATTRIBUTIONAL THEORY OF MOTIVATION AND EMOTION (Weiner, 1986:240) 
event is less important than its latent dimensionality (Weiner, 1986:121; Ployhart \& Harold, 2004).

Weiner postulates that there is a sequence involving three steps in which increasingly complex cognitive interpretations give rise to increasingly complex emotional reaction following an outcome (Weiner, 1986:121; Försterling, 2001:117-118)(Figure 3)

The emotion process begins with individuals evaluating whether or not they have reached their goal (e.g., whether the event is a success or failure); this stage is referred to as the "primary appraisal" (Weiner, 1986:121, 127). The outcome of an event initially results in a generally positive or negative affective reaction (a "primitive" emotion) such as happiness following success and frustration or sadness following failure outcomes (Weiner, 1986:121, 127). Weiner labelled these affective states "outcome dependent", for they are determined by the attainment or nonattainment of a desired goal, and not by the cause of that outcome. This first stage sequence is followed by "secondary appraisal" involving attributions to determine the cause for the outcome (for instance, low ability or bad luck) if the outcome was negative, unexpected or important (Weiner, 1986:127). These attributions result in a different set of emotions that is attribution-dependent and not outcome-dependent (Weiner, 1986:121; Oliver, 1989; Laufer, 2002). For instance, failure ascribed to "low ability" should give rise to the feeling of incompetence, whereas failure ascribed to bad luck should lead to the emotion of surprise. Finally, the individual determines the dimensional quality of the attribution by localising the specific cause on a causal dimension (e.g., locus, controllability and stability) leading to dimensiondependent emotions. For example, the individual might conclude that low ability is something internal to $\mathrm{him} /$ herself, and may hence experience low selfesteem and low self-worth (Weiner, 1986:163 \& 1992:279; Försterling, 2001:117).

One can illustrate that causal dimensions are related to specific emotions (Weiner, 1986:121; Fiske \& Taylor, 1991:429). Success and failure due to internal causes are anticipated to respectively result in greater or lower self-esteem (pride) than do external attributions (Weiner, 1986:121; Försterling, 2001:117). Anger follows from a negative outcome that is perceived as controllable by others, whereas gratitude follows from a positive outcome attributed to external and controllable factors. Guilt is the emotion probably experienced by one who causes negative outcomes for others or oneself, when those factors are controllable. Pity results from another person's negative outcome attributed to external factors that are seen as uncontrollable (Hewstone, 1989:67-68; Fiske \& Taylor, 1991:429). Uncontrollable causes are linked with shame (embarrassment, humiliation) (Weiner, 1986:135).

Causal stability may relate to future-oriented emotions such as "hope" and "fear" (Weiner, 1986:154; Fiske \& Taylor, 1991:52). This suggestion may be explained in terms of Weiner's argument that the causal dimen- sion of stability determines which influence a causal attribution will exert on the formation of expectancies following success and failure (expectancy change) (Weiner, 1986:154; Försterling, 2001:112). It is postulated that stable attributions for success should increase the expectancy of being successful at a subsequent similar task to a larger extent than variable attributions. In the same manner, stable attributions for failure decrease expectancies for future success more than the attribution of failure to variable causes (Weiner, 1986:94-95; Försterling, 2001:112). Therefore, failure attributed to stable factors implies the (fearful) anticipation that it will reoccur in future, whereas attribution of failure to variable causes could give rise to "hope" for the future (Försterling, 2001:117).

The quality of emotions is determined by locus and controllability factors, whereas the stability factor tends to intensify them. If a cause is seen as stable, the resulting affect will be more pronounced than if the cause is instable (Weiner in Fiske \& Taylor, $1991: 52,429)$. It is also assumed that the stability of the cause, rather than its locus, determines expectancy shifts (Weiner, 1986:85; Försterling, 2001:112).

Expectations and emotions are presumed to jointly determine subsequent achievement related performance (Weiner, 1986:164; Covington \& Omelich in Fiske \& Taylor, 1991:52). For example, one may persist when one attributes one's prior failing performance to unstable rather than stable factors, and these effects may be enhanced by feelings such as guilt over one's prior performance. Alternatively, one may give up if expectations of future success are low and feelings of hopelessness are high (Fiske \& Taylor, 1991:52; Försterling, 2001:109).

To summarise, Weiner's model incorporates a cognition-emotion-action process (Weiner, 2000; Laufer, 2002). The appraisal of an outcome as a success or failure leads to outcome-dependent emotions. Next, attributions are made that give rise to attributiondependent emotions. Finally, the individual determines the dimensional quality of the attributions, which in turn provoke dimension-dependent emotions and expectations for future outcomes. The differentiated affective reactions (generated by causal attributions and their underlying properties of locus, stability and controllability) are presumed to coexist with the initial general emotional response (Weiner, 1986:127; Weiner, 2000). Ultimately, these emotions and expectations are presumed to determine action (Weiner, 1986:164; Fiske \& Taylor, 1991:429). Weiner suggests that different outcomes, attributions and emotions lead to different behavioural consequences (Weiner, 1986:161-164; Folkes, 1988; Laufer, 2002).

\section{Weiner's attributional theory applied to consumer behaviour}

According to Weiner (2000), attribution theory is not only of use and interest to social psychologists, but to those in other branches of psychology and in related disciplines as well. During the last few years, the use 
of attribution theory in consumer behaviour has been found useful in explaining consumers' post-purchase behaviour (Folkes, 1988; Erevelles \& Leavitt, 1992; Laufer, 2002). The use of attribution theory in consumer behaviour has been found useful in explaining issues such as consumer satisfaction/dissatisfaction, complaint behaviour, word-of-mouth behaviour, redress seeking, and future repurchase intentions (Folkes, 1988; Erevelles \& Leavitt, 1992; Laufer, 2002; Vaidyanathan \& Aggarwal, 2003).

Most attribution studies on product failure apply Weiner's (1986) three-dimensional schema of attributional experience in understanding consumers' postpurchase behaviour (i.e. how consumers infer causes for product failure and how these attributions impact on behaviour) (Laufer, 2002, Vaidyanathan \& Aggarwal, 2003). While Folkes (1984) analysed all three causal dimensions and consumers' reactions to attributions based on those dimensions, there has been research that has examined the effect of one or two of these dimensions (Krishnan \& Valle, 1979; Richins, 1983; Oliver \& DeSarbo, 1988; Erevelles \& Leavitt, 1992).

Considering attribution theory, consumers are viewed as rational processors of information looking for reasons to explain why a purchase outcome turned out the way it did (Folkes, 1984; Erevelles \& Leavitt, 1992). In a consumer behaviour context, attributions arise when consumers evaluate the extent to which their initial product performance corresponds to their level of expectation concerning that product, followed by an attempt to find an explanation for the cause of the outcome (Weiner, 2000; Laufer, 2002). The most important causal agent for generating causal reasoning is the disconfirmation of expectations (Oliver, 1989; Pysznski \& Greenberg in Laufer, 2002). Unsatisfactory product experiences or product failures (events/outcomes which do not conform to expectation) are more likely to elicit causal search than positive experiences (product successes) would do (Weiner in Folkes, 1990:144; Weiner, 2000). "We (typically) do not ask why a product 'worked' but why it did not function" (Weiner, 2000:383).

In the context of Weiner's (1986) attributional theory, a consumer will first evaluate the product outcome/ event as "good for me" or "bad for me" (i.e. a success or failure). It is proposed that this primary evaluation will result in a primary affect, (e.g., the general state of happiness/sadness in response to the goodness or badness or the product event/outcome). The consumer will then search for the cause for product success or failure (secondary appraisal) by making an attribution, which will result in attribution-dependent emotions (Oliver, 1989). Ultimately, the specific cause will be positioned on a causal dimension leading to dimension-dependent emotions and expectations for future product success or failure. Causal attributions and their underlying dimension of locus, stability and controllability generate differentiated affective reactions which are thought to coexist with the initial primary affect generated by the goodness or badness of the product experience (Weiner, 2000). Conse- quently, general affective reactions linked to (product) outcome become further differentiated as more complex attributional thinking is incorporated into the process (Weiner, 2000). These emotions and expectations are thought to determine the consumer's behaviour.

Consistent with Weiner, Oliver (1989) proposes that based on the integration of general affective reaction and differentiated emotions, a summary judgment is formed which represents the common satisfied/ dissatisfied response. Differently stated, attributional processing is viewed as affecting satisfaction through distinct emotions in addition to primary evaluation which also affect satisfaction/dissatisfaction through primary affect (Dubé \& Schmitt, 1991; Manrai \& Gardner, 1991).

Consumers infer reasons for why a product performs well or badly and these reasons influence how they respond (Folkes, 1984; Curren \& Folkes, 1987). It is not merely the judgement that the product has failed that determines consumer response (Folkes, 1984). Weiner's causal dimensions (locus of causality, controllability and stability) have been linked to a variety of attributional consequences (emphasising distinctions among various behaviours, intentions and affects) following product failure (Curren.\& Folkes, 1987; Folkes, 1988 \& 1990:150-155; Ployhart \& Harold, 2004).

Locus of Causality In a consumer behaviour setting the locus of causality dimension refers to whether consumers believe that the cause for the event (success or failure with a product or the purchase outcome) can be attributed either to the consumer (internal) or to the manufacturer, retailer or some outside agent in the environment or situation or product itself (external) (Jones \& Nisbett in Williams, 1982:50; Erevelles \& Leavitt, 1992; Bitner in Oliver, 1993; Weiner, 2000; Laufer, 2002).

Consumers who feel dissatisfied because they did not follow the manufacturer's instructions when installing a dishwasher (internal attribution) will react differently to those who feel that the manufacturer is accountable for the defective dishwasher (external attribution). People who believe they received a bad product because of their inability to deal efficiently in the marketplace are making internal attributions. Similarly, those who feel dissatisfied because they did not spend enough time shopping are attributing the cause to themselves, the consumer. On the other hand, people who blame a "bad" product on the nature of the manufacturing company (Krishnan \& Valle, 1979) or the product per se ("This computer is not userfriendly") (Weiner, 2000), are making external attributions. Thus, locus of causality is based on who is perceived to be responsible for a given action (Vaidyanathan \& Aggarwal, 2003). According to Blodgett and Granbois' (1992) integrated conceptual model of consumer complaining, this variable should actually be referred to as attribution of blame.

Locus influences beliefs about who should solve 
problems: problems arising from consumers' actions should be solved by consumers, whereas problems arising from companies' (retailers or manufacturers) actions should be solved by companies (Folkes, 1988, 1990:151). Similarly, locus of causality influences whether consumers believe companies should provide restitution and redress (such as a refund or a replacement), and an apology for product failure. When product failures are externally attributed, consumers feel that they deserve refunds and apologies more than when they are internally attributed (Folkes, 1984, 1988, 1990:151; Erevelles \& Leavitt, 1992; Laufer, 2002; Laufer \& Gillespie, 2004). Locus of causality is also related to consumers' communications about negative outcomes. When the reasons for consumers' dissatisfaction are company-related, consumers are more inclined to complain to retailers and engage in negative word-of-mouth about products than when the reasons are consumer-related (Richins, 1983; Curren \& Folkes, 1987; Swanson \& Kelly, 2001). Additionally, external attributions may cause consumers to experience anger toward the company and they may consequently desire to do it harm. A number of studies have found that the greater the number of internal attributions (i.e. when consumers admit that products or retailers are not at fault), the greater the likelihood that consumers will do nothing when dissatisfied (Oliver in Laufer, 2002).

Controllability Both the consumer and other parties such as the manufacturer or retailer can either have volitional control over an outcome or be under certain uncontrollable constraints (Folkes, 1984; Erevelles \& Leavitt, 1992). This dimension reflects the power available to the different role-players to alter the outcome (Laufer, 2002; Weiner, 2000). The question is whether any of them has control over the factors that caused the situation to occur (Laufer, 2002).

Research has primarily examined how consumer' perceptions of retailers' control over a problem (external locus) influence consumers' responses to product failure (Folkes, 1990:152). If consumers attribute the cause of the problem to an external, uncontrollable cause, they will probably assign less blame to other entities such as the manufacturer or retailer. However, when failures are viewed as controllable, blame is targeted at the perceived entity that had control (Laufer, 2002). When retailers are thought to have control over the cause of product failure, consumers feel angry and desire revenge more than when they are believed to lack control (Folkes, 1984; 1988, 1990:152; Folkes et al, 1987). Anger intensifies as outcome importance increases; hence consumers will be more likely to complain to the company and/or public/private third parties, distance themselves from the company, refuse to repurchase the company's product and warn others against product purchase as opposed to uncontrollable, external product failures (Folkes et al, 1987; Folkes, 1988; Blogett \& Granbois, 1992; Swanson \& Kelly, 2001). Telling others about product failure enables individuals to vent their anger, to gain social support for the validity of these negative feelings and may allow them some means of retalia- tion by discouraging others from purchasing the product (Curren \& Folkes, 1987).

Stability In a consumer behaviour context, the stability dimension refers to whether the outcome of the purchase-use situation can be attributed to something temporary (unstable) or something that is likely to occur each time the product is purchased or used (stable) (Jones \& Nisbett in Williams, 1982:502; Folkes, 1990:155). For instance, when a washing machine stops because of a power failure once in a while, the cause is considered to be unstable, and when the machine stops because of a inherent defect the cause is considered to be stable.

Most of the previous studies of this dimension have been in the context of product failure (Oliver in Laufer, 2002). The stability dimension signals whether the same problem can be expected in the future or whether the event was perceived as a coincidence and not likely to recur in the future (Laufer, 2002). When product failure is stable, people should expect the product to fail if they purchased it again in the future. Conversely, when product failure is caused by unstable reasons, consumers should be less certain of future product failure (Folkes, 1984). If the attribution is unstable, consumers will view it as a once-off problem (Williams, 1982:503).

The stability dimension also influences the type of redress preferred when a product fails (Krishnan \& Valle, 1979; Folkes, 1988; Erevelles \& Leavitt, 1992). Compared with unstable reasons, stable attributions lead consumers to more strongly prefer refunds, rather than replacement of the failed product (Folkes, 1984; Vaidyanathan \& Aggarwal, 2003). Preference for refunds as opposed to replacement increases when products are perceived to fail for companyrelated reasons as opposed to consumer-related reasons. Consumers are thought more likely to warn friends against purchasing a product when they expect future product failure, than when they are uncertain about future product performance (Curren \& Folkes, 1987; Blogett \& Granbois, 1992). Curren and Folkes (1987) demonstrated that stable causes significantly increased the desire to warn friends but had little influence on desire to complain to companies. Consumers are equally likely to complain to a company about product failure whether the cause is stable or unstable. Furthermore, stability influences intention to repurchase. Inferring a stable cause leads to less desire to repurchase a product than does inferring an unstable cause. Additionally, consumers will probably vow to never again patronise that retailer and might even warn their friends about the retailer so that they may avoid the same type of problem (Folkes et al, 1987; Blogett \& Granbois, 1992).

It should be noted here that sometimes consequences of attributions are linked to a single causal dimension; for other consequences, more dimensions are involved (Curren \& Folkes, 1987; Folkes, 1988). 


\section{PROPOSED CONCEPTUAL FRAMEWORK}

Taking the foregoing literature in account the following schematic conceptual framework is proposed for research with the aim of understanding the consumer's complaint behaviour with regard to the performance failure of major electrical household appliances. This framework integrates three streams of consumer satisfaction/dissatisfaction (CS/D) and complaint behaviour (CB) research, namely the expectancy disconfirmation model (Churchill \& Suprenant, 1982; Bearden \& Teel, 1983) (satisfaction research), Weiner's (1986) causal dimensions (attribution theory), Day and Landon's (1977) taxonomy of complaint behaviour and consumer-related variables, and product-specific variables that may influence consumers' complaint behaviour (complaint behaviour theory). The dimensions presented in Figure 4 have been conceptualised using theoretical definitions found in the literature.

From the conceptual framework it is clear that prior to purchasing and using major electrical household appliances, consumers form expectations of its performance in a particular use situation. After or while using an appliance item consumers evaluate its perceived performance in terms of their initial expectations of the appliance's performance, relating to the functional and symbolic performance dimensions of the appliance. Whereas functional performance refers inter alia to durability, ease of use, ease of care and physical performance (how well the appliance does what it is supposed to do), symbolic performance refers to a "psychological" level of performance that is derived from the consumer's response to the physical product. When the appliance's performance does not meet the consumer's expectations (i.e. when a performance failure occurs or when the product performs poorly), negative disconfirmation occurs leading to feelings of dissatisfaction. Feelings of dissatisfaction are however mediated by attributional reasoning, i.e. the cognitive process of wanting to find out why a negative outcome or event has occurred. The perceived cause (attributions) for the product's failure and the dimensional quality thereof, in terms of Weiner's (1986) locus of causality, stability and controllability, influence consumers' reaction in terms of their emotions (the level of anger experienced in response to the product failure) and behaviours.

Consumer responses to dissatisfaction are generally referred to as "consumer complaint behaviour" (CCB) (Singh, 1988; Maute \& Forrester, 1993). Once dissatisfaction occurs the consumer may engage in behavioural and non-behavioural responses to resolve it (Day \& Landon, 1977:229-432; Broadbridge \& Mar-

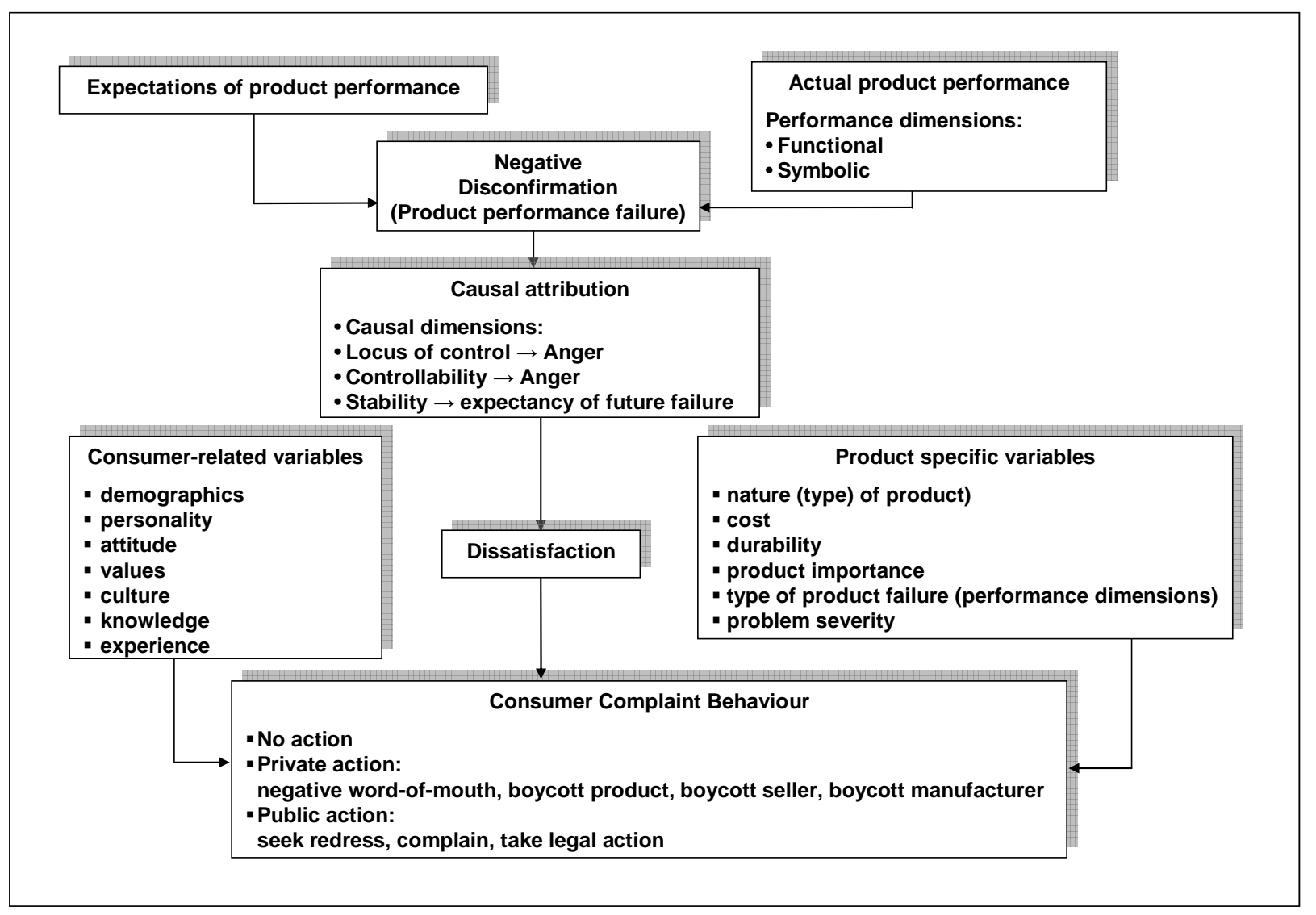

FIGURE 4: DISSATISFIED CONSUMERS' COMPLAINT BEHAVIOUR CONCERNING THE PERFORMANCE FAILURE OF MAJOR ELECTRICAL HUUSEHOLD APPLIANCES WITH CONSIDERATION OF ATTRIBUTIONAL PROCESSING, CONSUMER-RELATED VARIABLES AND PRODUCT-SPECIFIC VARIABLES 
shall, 1995). Three major options are available to consumers who are dissatisfied with their purchase: no action, private action or public action. Consumers may refrain from action by rationalising and forgetting about the problem. Consumers may engage in private actions such as switching brands or retailers, boycotting the type of product or warning family and friends. Consumers may also engage in public action such as seeking redress (i.e. a refund, an exchange or free repairs and replacement of defective parts depending on the nature of the product and particular circumstances) directly from the retailer or manufacturer, complaining to the retailer or manufacturer, a public consumer protection agency, a voluntary organisation or the media, or taking legal action against the retailer or manufacturer. However, consumer-related factors and product-specific factors are likely to affect the consumer's complaint behaviour. Consumer-related variables refer to characteristics that are associated or determined primarily by consumers. Demographics, personality, attitude, values, culture, knowledge and experience as consumer-related variables influence consumers' complaint behaviour. Productspecific variables, specifically the nature (type) of product, cost, durability, product importance, type of product failure (performance dimensions) and problem severity influence consumers' complaint behaviour.

The conceptual framework provides a schematic view of the reasoning behind the formulation of research questions for prospective studies concerning consumers' dissatisfaction with the performance failure of their major electrical household appliances.

\section{CONCLUSION}

A soundly planned conceptual framework is valuable as it arranges the research, assists the researcher to reach the research goals and renders results which in turn will contribute to establishing new theory (Babbie \& Mouton, 2002:107-113). The conceptual framework should, however, be based on a well-founded theory, where possible relationships between variables are clearly indicated and will assist the researcher to derive the research questions.

The suggested conceptual framework, as illustrated in Figure 4 , can be usefully applied in qualitative and quantitative research, with data-collecting methods such as questionnaires and focus groups, aimed at gaining a better understanding of consumers' complaint behaviour regarding the performance failure of major electrical household appliances.

It is essential that retailers and manufacturers understand how consumers reason and how they explain unexpected negative outcomes such as product failures. Accordingly, researchers should recognise that the framework for this type of research should be based on a theoretical perspective that concentrates on the underlying perceptions and cognitions that people use to make judgements about other people, events and objects. It should not only be seen as an academic activity, but should be part of the marketing strategy of all businesses who are serious about retaining loyal customers.

Research questions that could emerge from such a conceptual framework that would be of immense value within the South African context, include:

- What is the relationship between specific consumer-related variables (i.e. demographics, personality, attitude, values, culture, knowledge and experience) and dissatisfied consumers' complaint behaviour concerning the performance failure of selected major electrical household appliances?

- What is the relationship between dissatisfied consumers' perception of the severity of the product problem (product-specific variable) and their complaint behaviour concerning the performance failure of selected major electrical household appliances?

- What type of consumer complaint behaviour responses do dissatisfied consumers engage in concerning their dissatisfaction with the functional/ symbolic performance failure of selected major electrical household appliances?

- What is the relationship between causal attribution and dissatisfied consumers' complaint behaviour concerning the performance failure of selected major electrical household appliances?

Consumer research focusing on consumers' postpurchase expectations and levels of (dis)satisfaction, attributions for product failure and complaint behaviour should be part of an ongoing plan to improve products, to protect and ensure consumers' rights and to improve business.

\section{LIST OF REFERENCES}

ABRAHAM-MURALI, L \& LITTRELL, MA. 1995. Consumers' conceptualisation of apparel attributes. Clothing and Textiles Research Journal 13(2):65-74. BABBIE, E \& MOUTON, J. 2002. The practice of social research. South African edition. Cape Town. Oxford University Press. Southern Africa.

BARNES, JG \& KELLOWAY, KK. 1980. Consumerists: complaining behavior and attitudes toward social and consumer issues. Advances in Consumer Research 7(1):329-334.

BEARDEN, WO \& OLIVER, RL. 1985. The role of public and private complaining in satisfaction with problem resolution. Journal of Consumer Affairs. 19 (2):222-240.

BEARDEN, WO \& TEEL, JE. 1983. Selected determinants of consumer satisfaction and complaint reports. Journal of Marketing Research 20:21-28.

BENNET, R. 1997. Anger, catharsis, and purchasing behavior following aggressive customer complaints. Journal of Consumer Marketing 14(2):156-172. BLODGETT, J \& GRANBOIS, D. 1992. Toward an integrated conceptual model of consumer complain- 
ing behavior. Journal of Consumer Satisfaction, Dissatisfaction and Complaint Behavior 5:93-103.

BOLFING, C. 1989. How do customers express dissatisfaction and what can service marketers do about it? Journal of Services Marketing 3(2):5-23.

BOUGIE, R, PIETERS, R \& ZEELENBERG, M. 2003. Angry customers don't come back, they get back: the experience and behavioral implications of anger and dissatisfaction in services. Journal of the Academy of Marketing Science 31(4):377-393.

BROADBRIDGE, A \& MARSHALL, J. 1995. Consumer complaint behavior: the case of electrical goods. International Journal of Retail \& Distribution Management 23(9):8-18.

BROWN, P \& RICE, J. 1998. Ready-to-wear apparel analysis. 2 nd ed. Upper Saddle River, NJ. MerrillPrentice-Hall.

CHEN-YU, HJ, WILLIAMS, G \& KINCADE, DH. 1999. Determinants of consumer satisfaction/dissatisfaction with the performance of apparel products. Family and Consumer Sciences Research Journal 28(2):167-192. CHURCHILL, GA \& SUPRENANT, C. 1982. An investigation into the determinants of customer satisfaction. Journal of Marketing Research 19(Nov):491-504.

CLOPTON, SW, STODDARD, JE \& CLAY, JW. 2001. Salesperson characteristics affecting consumer complaint responses. Journal of Consumer Behavior 1 (2):124-139.

CONSUMER ALERT. 2003. How to complain effectively. Consumers' Research Journal (Feb):34-45. Available on line. www.consumeralert.org. Accessed 01/04/2005

CURREN, MT \& FOLKES, VS. 1987. Attributional influences on consumers' desires to communicate about products. Psychology \& Marketing 4:31-45.

DAVIS, LL \& LENNON, SJ. (1991). Social cognition and the study of clothing and human behavior. ITAA special publication 4:182-190.

DAY, RL. 1977. Extending the concept of consumer satisfaction. Advances in Consumer Research 4 (1):149-154.

DAY, RL. 1984. Modeling choices among alternative responses to dissatisfaction. Advances in Consumer Research 4(1):496-499.

DAY, RL \& BODUR, M. 1978. Consumer response to dissatisfaction with services and intangibles. Advances in Consumer Research 5(1):263-272.

DAY, RL, GRABICKE, K, SCHAETZLE, $T$ \& STAUBACH, F. 1981. The hidden agenda of consumer complaining. Journal of Retailing 78(2):86-106. DAY, RL \& LANDON, EL (Jr). 1976. Collecting comprehensive consumer complaint data by survey research. Advances in Consumer Research 3(1):263268.

DAY, RL \& LANDON, EL (Jr). 1977. Toward a theory of consumer complaining behavior. In Woodside, AG, Sheth, IN, Bennet, PD. Consumer and industrial buying behavior. New York. North-Holland.

DOLINSKY, AL. 1994. A consumer complaint framework with resulting strategies. An application to higher education. Journal of Services Marketing 8(3):27-39. DONOGHUE, S. 1998. 'n Verkennend-beskrywende ondersoek na die rol van sosiale motiewe en verbruikerstereotipering by bepaalde swart, vroulike opkomende verbruikers se keuse van groot elektriese huishoudelike toerusting. Skripsie vir Magistergraad in Huishoudkunde. Pretoria. Universiteit van Pretoria. DUBÉ, L \& SCHMITT, BH. 1991. The processing of emotional and cognitive aspects of product usage in satisfaction judgments. Advances in Consumer Research 18(1):52-56.

ERASMUS, AC. 1998. A suggested approach to educating consumers on the purchase of electrical household appliances. Journal for Family Ecology and Consumer Sciences 26(2):145-151.

ERASMUS, AC \& DONOGHUE, S. 1998. Consumer satisfaction - an unattainable ideal? Journal for Family Ecology and Consumer Sciences 26(1):35-42.

EREVELLES, S \& LEAVITT, C. 1992. A comparison of current models of consumer satisfaction/ dissatisfaction. Journal of Consumer Satisfaction, Dissatisfaction and Complaint Behavior 5:104.

FISKE, ST \& TAYLOR, SE. 1991. Social cognition. 2nd ed. New York. McGraw-Hill.

FOLKES, VS. 1984. Consumer reactions to product failure: an attributional approach. Journal of Consumer Research 10:398-409.

FOLKES, VS. 1988. Recent attribution in consumer behavior: a review and new directions. Journal of Consumer Research 14:548-565.

FOLKES, VS. 1990. Conflict in the market place: explaining why products fail. In Graham, S \& Folkes, VS. Attribution theory: Applications to achievement, mental health and interpersonal conflict. New Jersey. Lawrence Erlbaum associates.

FOLKES, VS, KOLETSKY, S \& GRAHAM, JL. 1987. A field study of causal inferences and consumer reaction: the view from the airport. Journal of Consumer Research 13(March):534-539.

FÖSTERLING, F. 2001. Attribution: an introduction to theories, research, and applications. East Sussex. Psychology Press.

FRANCKEN, DA. 1983. Post-purchase consumer evaluations, complaint actions and repurchase behavior. Journal of Economic Psychology 4:273-290.

GOODWIN, C \& ROSS, I. 1990. Consumer evaluations of responses to complaints: what's fair and why. Journal of Consumer Marketing 7(2):39-47.

GOODWIN, C \& SPIGGLE, S. 1989. Consumer complaining: attributions and identities. Advances in Consumer Research 16(1):17-22.

HALSTEAD, D \& DRÖGE, C. 1991. Consumer attitudes toward complaining and the prediction of multiple complaint responses. Advances in Consumer Research 18:210-216.

HAWKINS, DI, BEST, RJ \& CONEY, KA. 1998. Consumer behavior. Building marketing strategy. 7th ed. Boston. Irwin/McGraw-Hill.

HEWSTONE, M. 1989. Causal Attribution. From cognitve processes to collective beliefs. Oxford. Blackwell.

HILL, DJ, BAER, RB \& MORGAN, AJ. 2000. Excuses: use 'em if you got 'em. Advances in Consumer Research 27(1):87-91.

HIRSCHMAN, AO. 1970. Exit, voice and loyalty: responses to decline in firms, organizations and states. Cambridge, MA. Harvard University press.

HOGARTH, JM \& ENGLISH, MP. 2002. Consumer complaints and redress: an important mechanism for protecting and empowering consumers. International 
Journal of Consumer Studies 26(3):217-226.

KELLY, HH \& MICHELA, JL. 1980. Attribution theory and research. Annual Review of Psychology. 31:457501.

KENG, KA \& LIU, S. 1997. Personal values and complaint behavior: the case of Singapore consumers. Journal of Retailing and Consumer Services 4(2):8997.

KINCADE, DH, GIDDINGS, VL \& CHENYU, HJ. 1998. Impact of product specific variables on consumers' post-consumption behavior for apparel products: USA. Journal of Consumer Studies and Home Economics 22(2):81-90.

KRISHNAN, S \& VALLE, VA. 1979. Dissatisfaction attributions and consumer complaint behavior. Advances in Consumer Research 6(1):445-449.

LANDON, EL (Jr). 1980. Consumer satisfaction, dissatisfaction and complaining behavior as indicators of market performance. Advances in Consumer Research 7(1):186-191.

LAUFER, D. 2002. Are antecedents of consumer dissatisfaction and consumer attributions for product failures universal? Advances in Consumer Research 29:312-317.

LAUFER, D \& GILLESPIE, K. 2004. Differences in consumer attributions of blame between men and women: the role of perceived vulnerability and empathic concern. Psychology \& Marketing 21(2):141157.

LENNON, SJ \& DAVIS, LL. (1989): Clothing and human behavior from a social cognitive framework. Part I: Theoretical perspectives. Clothing and Textile Research Journal 7(4):41-48.

LIU, RR \& McCLURE, P. 2001. Recognizing crosscultural differences in consumer complaint behavior and intentions: an empirical examination. Journal of Consumer Marketing 18(1):54-75.

LOUDON, DL \& DELLA BITTA, AJ. 1993. Consumer behavior: concepts and applications. 4 th ed. New York. McGraw-Hill.

MANRAI, LA \& GARDNER, MP. 1991. The influence of affect on attributions for product failure. Advances in Consumer Science 18:249-254.

MAUTE, MF \& FORRESTER, WR, (Jr). 1993. The structure and determinants of consumer complaint intentions and behavior. Journal of Economic Psychology 14:219-247.

MCALISTER, DT \& ERFFMEYER, RC. 2003. A content analysis of outcomes and responsibilities for consumer complaints to third-party organizations. Journal of Business Research 56:341-351.

MOREL, KPN, POIESZ, TBC \& WILKE, HAM. 1997. Motivation, capacity and opportunity to complain: Towards a comprehensive model of consumer complaint behaviour Advances in Consumer Research 24 (1):464-469.

NYER, PU. 2000. An investigation into whether complaining can cause increased consumer satisfaction. Journal of Consumer Marketing 17(1):9-19.

OLIVER, RL. 1987. An investigation of the interrelationship between consumer (dis)satisfaction and complaint reports. Advances in Consumer Research 14 (1):218-222.

OLIVER, RL. 1989. Processing of the satisfaction response in consumption: a suggested framework and research propositions. Journal of Consumer Satisfaction, Dissatisfaction and Complaint Behavior 2:116.

OLIVER, RL. 1993. Cognitive, Affective, and Attribute bases of the satisfaction response. Journal of Consumer Research 20(3):418-431.

OLIVER, RL \& DeSARBO, WS. 1988. Response determinants in satisfaction judgments. Journal of Consumer Research 14:495-507.

PERKINS, DS. 1993. An update of the CS/D\&CB bibliography: revolution and evolution. Journal of Consumer Satisfaction, Dissatisfaction and Complaint Behavior 6:217-279.

PLOYHART, ER \& HAROLD, CM. 2004. The applicant attribution-reaction theory (AART): an integrative theory of applicant attributional processing. International Journal of Selection and Assessment 12 (1/2):84-98.

PLYMIRE, J. 1991. Complaints as opportunities. Journal of Consumer Marketing/Service Marketing 8 (2):39-43.

RICHINS, ML. 1982. An investigation of consumers' attitudes toward complaining. Advances in Consumer Research 9(1):502-506.

RICHINS, ML. 1983. Negative word-of-mouth by dissatisfied consumers: a pilot study. Journal of Marketing 47 (Winter):68-78.

RICHINS, ML. 1987. A multivariate analysis of responses to dissatisfaction. Journal of the Academy of Marketing Science 15(3):24-31.

RICHINS, ML \& VERHAGE, BJ. 1985. Seeking redress for consumer dissatisfaction: the role of attitudes and situational factors. Journal of Consumer Policy 8(1):29-44.

ROUSSEAU, D. 2003. Consumerism and social responsibility in DU PLESSIS, PJ \& ROUSSEAU, GG. Buyer Behaviour. A multi-cultural approach to consumer decision-making in South Africa. Cape Town. Oxford University Press.

ROUSSEAU, GG. 1988. Consumer and retail perceptions of product failure: who is responsible? Journal of Industrial Psychology 14(1):12-17.

SANES, C. 1993. Complaints are hidden treasures. The Journal for Quality and Participation 16(5):78-83.

SHETH, JN, MITTAL, B, \& NEWMAN, BI. 1999. Customer behavior: consumer behavior and beyond. Fort Worth. Dryden Press.

SINGH, J. 1988. Consumer complaint intentions and behavior: definitional and taxonomical issues. Journal of Marketing 52:93-107.

SINGH, J. 1990a. Identifying consumer dissatisfaction response styles: An agenda for future research. European Journal of Marketing 24(6):55-72.

SINGH, J. 1990b. A typology of consumer dissatisfaction response styles. Journal of Retailing 66(1):57-99. SINGH, J \& WILKES, RE. 1996. When consumers complain: A path analysis of the key antecedents of consumer complaint response estimates. Journal of the Academy of Marketing Science 24(4):350-365.

SIRGY, MJ. 1983. Social cognition and consumer behavior. New York. Praeger.

SOMASUNDARAM, TN. 1993. Consumers' reaction to product failure: impact of product involvement and knowledge. Advances in Consumer Research 20:215218. 
STEPHENS, N \& GWINNER, KP. 1998. Why don't some people complain? A cognitive-emotive process model of consumer complaint behavior. Journal of the Academy of Marketing Science 26(3):172-189.

SWAN, JE \& COMBS, LJ. 1976. Product performance and consumer satisfaction. Journal of Marketing 40:25-33.

SWAN, JE \& OLIVER, RL. 1989. Post-purchase communications by consumers. Journal of Retailing 65 (4):516-533.

SWANSON, SR \& KELLY, SW. 2001. Attributions and outcomes of the service recovery process. Journal of Marketing (Fall):50-65.

VAIDYANATHAN, R \& AGGARWAL, P. 2003. Who is the fairest of them all? An attributional approach to price fairness perceptions. Journal of Business Research 56:453-463.
WEINER, B. 1986. An attributional theory of motivation and emotion. New York. Springer-Verlag.

WEINER, B. 1992. Human motivation. Metaphors, theories and research. Newbury Park. Sage.

WEINER, B. 2000. Attributional thought about consumer behavior. Journal of Consumer Research 27 (3):382-387.

WESTBROOK, RA. 1987. Product/consumptionbased affective responses and post-purchase processes. Journal of Marketing Research 24:250-270.

WILLIAMS, TG. 1982. Consumer behavior. New York. West.

WOODRUFF, RB, CADOTTE, ER \& JENKINS, RL. 1983. Modelling consumer satisfaction processes using experience based norms. Journal of Marketing Research 20(Aug):296-304. 